\title{
PRZYJEMNOŚĆ CZYTANIA, UDRĘKA WYBORU. O NIEKTÓRYCH TECHNOLOGIACH WYKRYWALNOŚCI I REKOMENDACJI KSIĄŻEK W SIECI
}

\begin{abstract}
Wybór książki jako element zachowań czytelniczych i konsumenckich. Dostępność i ekspozycja bieżącej oferty wydawniczej w sieci. Automatyczne rekomendacje książek. Wady i zalety automatycznych serwisów rekomendacji książek.
\end{abstract}

SŁOWA KLUCZOWE: czytelnictwo, rynek książki, wykrywalność książki, wyszukiwalność książki, systemy rekomendacji książek

Akt lektury jest zwieńczeniem wielu działań podejmowanych przez podmioty współdziałające w ramach systemu, który na gruncie nauki o książce określany jest mianem komunikacji bibliologicznej (Zawisza, 1980; Woźniak-Kasperek, Kotuła, 2014). Produkt końcowy procesów wydawniczych i dystrybucyjnych w postaci książki drukowanej i/lub cyfrowej zapewnia czytelnikowi dostęp do wiedzy poszerzającej jego horyzonty intelektualne oraz informacji przydatnych w praktyce, ale także - a niekiedy przede wszystkim — dostarcza mu przyjemności wynikającej z kontaktu z umysłowością i wrażliwością autora, uobecnionych w materii tekstu. Realizacja kolejnych aktów lekturowych kształtuje doświadczenie czytelnika, a ich jakość i skutki decydują o roli, jaką odgrywa książka w jego życiu. Czynnością poprzedzającą akt lektury jest wybór tekstu do czytania, co również wpływa na występowanie uczucia satysfakcji lub jego braku w kontaktach z literaturą lub szeroko rozumianym piśmiennictwem. Książka niewłaściwie dobrana może skutecznie zniechęcić do czytania w ogóle lub na pewien czas. Dokonywanie właściwej selekcji przez czytelników jest zatem równie ważne $\mathrm{z}$ ich perspektywy, jak i z punktu widzenia interesów wszystkich zaangażowanych w obieg piśmiennictwa instytucji. Uporczywe niepowodzenia lekturowe obejmujące książki 
wypożyczone z biblioteki mogą kojarzyć się z jej ogólną nieprzydatnością. Źle dobrane tytuły w księgarni oznaczają chybione inwestycje, które mogą skutkować pytaniem, czy warto płacić za produkty niespełniające oczekiwań nabywcy. Wybór książki jest zatem aktywnością, której przebieg i skutki mają znaczenie zarówno dla odbiorców tekstów piśmienniczych (czytelników), jak i ich producentów (wydawców) oraz dystrybutorów (księgarzy oraz bibliotekarzy). Coraz powszechniej stosowane $\mathrm{w}$ środowisku sieciowym mechanizmy zapewniające odpowiednią widoczność i wyszukiwalność produktów książkowych stanowią istotne wsparcie $\mathrm{w}$ procesach decyzyjnych obejmujących zakup, wypożyczenie czy też przeczytanie lektury. Wśród dostępnych narzędzi teleinformatycznych szczególnym zainteresowaniem cieszą się automatyczne rekomendacje książek, które zostały szczegółowo omówione w dalszej części artykułu.

\section{WYBÓR KSIĄŻKI JAKO ELEMENT ZACHOWAŃ CZYTELNICZYCHIKONSUMENCKICH}

Wybór lektury jest jednym z integralnych elementów złożonego procesu uczestnictwa w kulturze książki. Obok sposobu odbioru stanowi on składnik zachowań czytelniczych poprzedzający akt lektury. Zachowania czytelnicze z kolei są konsekwencją określonych postaw czytelniczych, ukształtowanych przez stosowną motywację, zrodzoną przez potrzeby, autonakazy bądź nakazy zewnętrzne (Wojciechowski, 1999, s. 119). Motywy czytania wiążą się również z określonymi oczekiwaniami wobec lektury, jego celami, a także pobudkami sięgania po książkę, wyrażającymi się w preferowaniu pewnych informacji, wątków, sytuacji czy ogólnej wymowy utworu. Ich zróżnicowany charakter oddaje podział na motywy instrumentalne (w kontekście których czytanie jest środkiem osiągnięcia konkretnego celu utylitarnego: uzyskania wykształcenia czy wiedzy umożliwiającej realizację zadań, zdobycia prestiżu społecznego itp.) i autoteliczne (które łączą się z chęcią doświadczania przeżyć natury intelektualnej, estetycznej i emocjonalnej) (Andrzejewska, 1989, s. 34-35). Zachowania czytelnicze obejmujące wybory i preferencje czytelnicze, procesy recepcji lektury oraz ogólną aktywność czytelnika wskazują na sposób partycypacji odbiorców tekstów piśmienniczych w kulturze książki (Andrzejewska, 1989, s. 40). Jej funkcjonowanie zależy jednak również od ekonomicznych zabiegów na rzecz nabywania produktów książkowych, podejmowanych przez członków określonych społeczności w celu zaspokojenia potrzeb. Kupowanie książek należy do kategorii zachowań konsumenckich, które mają charakter wieloetapowy i uwzględniają procesy wyboru, kupna oraz użytkowania dóbr (Sobczyk, 2018). 
Wybory czytelnicze są zatem zgodne z zainteresowaniami i potrzebami osób sięgających po książki; wynikają one z ich dotychczasowych doświadczeń lekturowych i kontekstu społecznego, w którym odbywa się czytanie, oraz wskazują na ich oczekiwania wobec tekstu (Andrzejewska, 1989, s. 41; Zasacka, 2009, s. 81). Selekcja książki następuje przed aktem lektury, nie zawsze jednak musi ją bezpośrednio poprzedzać, ponieważ może być dokonywana również w odniesieniu do tytułów, które mają zostać przeczytane w bliżej nieokreślonej przyszłości. Intencją osoby decydującej się na pozyskanie danej książki może w ogóle nie być jej lektura, jeśli jej wybór jest elementem zachowań konsumenckich towarzyszących kupowaniu prezentów lub realizacji innych celów (dekoracja mieszkania, określenie statusu społecznego nabywcy itp.). Dobór książki, dokonywany w różnych okolicznościach, może zostać poprzedzony długotrwałym procesem poszukiwawczym, ale może też niekiedy zostać sprowadzony do błyskawicznej, podjętej pod wpływem impulsu, decyzji o kupnie lub wypożyczeniu konkretnego tomu.

Wśród czynników, które warunkują wybór określonych książek, szczególną rolę odgrywają źródła informacji o nich. Stopień ich wykorzystania i skuteczność w zakresie zaspokajania potrzeb informacyjnych osób sięgających po literaturę stanowi przedmiot analiz w badaniach nad czytelnictwem, bibliotekami i rynkiem wydawniczym. Uwzględniają je na przykład cykliczne raporty Biblioteki Narodowej. W analizie stanu czytelnictwa w Polsce w 2018 roku zapytano uczestników badania o przydatność źródeł wiedzy na temat tego, jakie książki warto czytać (Koryś, Chymkowski, 2019). Wśród wskazanych inspiracji lekturowych pojawiły się następujące propozycje: samodzielna ocena zawartości, rodzina, znajomi, inni czytelnicy w internecie, bibliotekarze, księgarze, dziennikarze i krytycy (prasa, radio, telewizja), nagrody literackie, listy bestsellerów, reklamy i katalogi, wygląd i okładka. Okazało się, że największy wpływ na dobór książek miały rekomendacje znajomych i rodziny oraz własne kompetencje czytelnicze. Osobno zostały poddane ocenie źródła w grupie nabywców książek, co sugerowało ich wpływ na decyzje zakupowe. W tym przypadku badani kierowali się przede wszystkim własną opinią na temat danej pozycji, a dopiero w dalszej kolejności poleceniami znajomych i rodziny. Ponadto osoby stosunkowo młode (do 39. roku życia) z tej grupy częściej sięgały do ocen książek zamieszczanych w internecie. Natomiast najstarsi respondenci większą wagę przywiązywali do sądów bibliotekarzy i księgarzy. Z kolei najmniejszym zaufaniem we wszystkich grupach wiekowych obdarzano komunikaty rozpoznawane jako jednoznacznie komercyjne (reklamy, katalogi wydawnicze itp.). Wyniki przeprowadzonego w 2020 roku badania na temat źródeł wiedzy o książkach wartych przeczytania potwierdziły kluczowe znaczenie rekomendacji od znajomych i rodziny oraz ujawniły zrównanie roli internetu i samodzielnego kontaktu z książką i utrzymanie się niskiej oceny ko- 
munikatów reklamowych i informacyjnych, których celem jest promocja bieżącej oferty wydawniczej w mediach (Chymkowski, Zasacka, 2021).

Analizy wyborów dokonywanych w bibliotekach obejmują zarówno zachowania czytelników w tego typu miejscach, jak i sposoby wykorzystywania przez nich katalogów bibliotecznych. Zgodnie z wynikami badań przedstawionymi przez Annę Mikkonen i Perttiego Vakkariego (2016) na selekcję książki do czytania dla przyjemności w bibliotekach wpływ ma wiele czynników: nabyta wiedza literacka, preferencje lekturowe, czynniki osobiste i emocjonalne (na przykład nastrój czytelnika) oraz same książki (w szczególności ich okładki czy zawarte w nich komunikaty promocyjne). Ważne są również recenzje rodziny lub przyjaciół. Przy szukaniu tytułów do czytania jako rozrywki (najczęściej beletrystyki) czytelnicy kierują się głównie znajomością autora i sami aktywnie poszukują w książce stosownych wskazówek, przeglądając pobieżnie jej treść oraz zaznajamiając się z tekstem widniejącym na czwartej stronie okładki. W poszukiwaniach lektur uwagę użytkowników biblioteki przyciągają również półka z nowościami i miejsce ze zwrotami wypożyczonych tytułów. Zastosowanie katalogów bibliotecznych w tym celu prowadzi do wyboru autorów, których czytelnik już zna, oraz selekcji tytułów na podstawie rekomendacji mediów.

Innym niż wypożyczenie sposobem wejścia w posiadanie książki do czytania jest jej nabycie. We wspomnianym raporcie Stan czytelnictwa w Polsce $w 2018$ roku zasygnalizowano, że znaczenie zakupów książkowych stale rosło (z 31\% w 2014 roku do 38\% w 2018 roku) (Koryś, Chymkowski, 2019). W analizie za 2020 rok odsetek ten był jeszcze większy i wyniósł 45\%. Kolejne źródła, z których pozyskiwano tytuły do czytania, wskazywane były w tym badaniu rzadziej: prezent (34\%), znajomi (32\%), biblioteki (23\%), księgozbiór domowy (20\%). Zwiększył się również odsetek czytelników płacących za e-booki lub za abonament zapewniający dostęp do nich (49\%) (Chymkowski, Zasacka, 2021). Wybieranie książki podczas zakupów również wiąże się z różnymi uwarunkowaniami. Członkowie rodziny czy znajomi mogą stymulować chęć nabycia konkretnego tytułu, jednak nie będą obecni przy każdej sytuacji związanej z kupowaniem książki. Klient księgarni, dokonując wyboru z dostępnej oferty, może zatem brać pod uwagę inne czynniki, które decydują o jego zachowaniach konsumenckich, jak chociażby cena produktu. Przyciągająca wzrok okładka czy interesująca szata graficzna również mogą skłonić do nabycia książki, podobnie jak intrygująco napisany blurb czy inne zamieszczone na obwolucie informacje od wydawcy. Bodźcem wpływającym na decyzje zakupowe jest ponadto odpowiednia ekspozycja asortymentu w księgarni - zarówno stacjonarnej, jak i internetowej. Na wzrost zainteresowania konkretnymi tytułami wpływ mają także zastosowane przez wydawców narzędzia marketingowe i promocyjne. Daniel Bunyard, dyrektor wydawniczy Penguin Random House UK, w artykule Why we buy books (2020, s. 29) wskazał, 
że ogólnie sprzedaż książki jest wypadkową dwóch czynników — jej dostępności i wzbudzanego przez nią zainteresowania czy wręcz pożądania. Nawet najbardziej atrakcyjna publikacja nie sprzeda się, jeśli nie zagości w świadomości czytelników i nie będzie szeroko dostępna na rynku. Podobnie tytuł, który jest szeroko reklamowany i dystrybuowany, nie znajdzie nabywców, jeśli nie stanie się przedmiotem pożądania. Brytyjski wydawca zaznaczył przy tym, że potencjalna dostępność (na którą wpływa wydawca poprzez reklamę, marketing itp.) jest tak samo kluczowa jak rzeczywista dostępność (określona przez głębokość i szerokość ekspozycji detalicznej i zasięgu na rynku oraz różnorodność formatów). Atrakcyjność pożądanych tytułów Bunyard połączył natomiast ze stopniem zgodności ich treści z motywacjami psychologicznymi nabywców książek, funkcjonujących w określonym kontekście historycznym.

Ogólnie czynniki wpływające na wybór książki można zatem podzielić na: podmiotowe, przedmiotowe i środowiskowe. Czynniki podmiotowe wiążą się z osobą dokonującą wyboru - czytelnikiem, klientem księgarni oraz użytkownikiem biblioteki. W tej kategorii mieszczą się potrzeby i motywacje, zarówno czytelnicze, jak i konsumenckie (na przykład związane z zakupem książki do własnego księgozbioru lub jako prezentu), a także kompetencje literackie danej osoby czy jej ogólna znajomość świata literatury. Na wybór książki do czytania istotny wpływ mają również dotychczasowe doświadczenia i preferencje lekturowe czytelnika, a także jego kondycja fizyczna i psychiczna. $Z$ kolei czynniki przedmiotowe odnoszą się do atrybutów wybieranej pozycji i uwzględniają jej autora, cenę, szatę graficzną (w tym okładkę), dostępność, a także towarzyszące jej komunikaty promocyjne i informacyjne. Natomiast czynniki środowiskowe uwzględniają okoliczności wyboru książki oraz wpływ otoczenia na osobę, która go dokonuje. Okoliczności wyznaczane są przez profil, wielkość i lokalizację zbiorów książek stanowiących podstawę dokonywanej selekcji. Mogą to zatem być księgozbiory domowe (własne lub innych czytelników) i biblioteczne, asortyment księgarni stacjonarnej czy internetowej, a także oferta wydawnicza prezentowana na targach książki. Do czynników środowiskowych należą również spersonalizowane źródła informacji o książkach, których charakter określają kontakty międzyludzkie z innymi czytelnikami lub osobami zawodowo zajmującymi się książkami. Są to ludzie z bliskiego (rodzina, a także znajomi, zarówno ze świata realnego, jak i wirtualnego) lub dalszego (księgarze czy bibliotekarze) kręgu danego czytelnika. Zdepersonalizowane źródła informacji o książkach mają charakter dokumentacyjny i przeznaczone są dla wszystkich zainteresowanych literaturą czy ogólnie piśmiennictwem. Do tej grupy zaliczyć można między innymi programy telewizyjne i audycje radiowe poświęcone książkom, czasopisma i blogi literackie, portale recenzenckie, serwisy społecznościowe dla czytelników (na przykład LibraryThing, Goodreads, Lubimyczytać) czy profile miłośników ksią- 
żek w mediach społecznościowych (na Facebooku, Twitterze, Instagramie itp.). Trzecia kategoria czynników środowiskowych łączy się z procesami oddziałującymi na czytelnika dokonującego wyboru książki. Pod tą ogólną nazwą mieści się marketing wydawniczy wraz z promocją i reklamą, działalność informacyjna bibliotek, realizacja misji publicznej przez media itp.

Osoba dokonująca wyboru książki kieruje się zatem określonymi przesłankami i informacjami. Na jej decyzje wpływ mają odpowiednie działania instytucji współtworzących obieg dokumentów piśmienniczych. Podstawą funkcjonowania tego systemu jest aktywność wydawnictw w zakresie zapewniania informacji o ich bieżącej ofercie, a niekiedy wręcz skierowanie uwagi klientów na konkretne produkty książkowe, które odpowiadają zróżnicowanym kategoriom ich potrzeb.

\section{DOSTĘPNOŚĆ I EKSPOZYCJA BIEŻĄCEJ OFERTY WYDAWNICZEJ W SIECI}

Pod koniec XX wieku internet stał się istotnym pośrednikiem w komunikacji między wydawcą a czytelnikiem ze względu na coraz częstsze umieszczanie w nim informacji o nowościach wydawniczych oraz uruchomienie nowego kanału sprzedaży książek w postaci księgarń internetowych. Sieć drugiej generacji (Web 2.0) stworzyła z kolei nowe perspektywy w zakresie społecznej wymiany opinii o książkach. Zainteresowanie internautów publikacjami drukowanymi zapewniło również wydawcom nowe możliwości promocji i reklamy ich produktów.

Rosnące zaangażowanie narzędzi teleinformatycznych w społeczny obieg treści piśmienniczych ostatecznie spowodowało przekształcenie ról wszystkich podmiotów funkcjonujących na rynku książki. Co prawda autorzy w dalszym ciągu piszą książki, wydawcy je wydają, a czytelnicy kupują, wypożyczają i czytają, jednak w obecnej rzeczywistości komunikacyjnej, konsumpcyjnej i kulturowej każda $\mathrm{z}$ tych grup realizuje również nowe zadania. Pisarze coraz częściej przejmują procesy związane z produkcją książek lub w nich współuczestniczą, a także podejmują działania promocyjne. Aktywność pisarską wykazują również czytelnicy, którzy jednak przede wszystkim stali się integralnym elementem systemu opiniowania i oceniania książek za sprawą recenzji czy liczby „gwiazdek” lub „lajków” przyznawanych przeczytanym lekturom. Wydawcy z kolei bardziej intensywnie zajmują się dystrybucją oraz wykorzystaniem narzędzi informatycznych i mediów społecznościowych w strategiach marketingowych (Baverstock, 2019). Dotychczasowy system obiegu treści piśmienniczych od autora przez wydawcę i dystrybutora do czytelnika traci swój liniowy charakter na rzecz siatki wzajemnych powiązań i relacji, w których przenikają się aspekty twórcze, produkcyjne, marketingowe, opiniotwórcze i recepcyjne. Twórca zatem coraz częściej komunikuje się bezpośrednio z czytelnikiem za pomocą swojej witryny interne- 
towej czy profilu w serwisie społecznościowym. Z tego typu mediów korzystają również czytelnicy, aby wymieniać się informacjami i doświadczeniami z innymi osobami. Do nich z kolei odwołują się wydawcy w celu wykorzystania potencjału wirtualnych społeczności w strategiach marketingowych. Technologie teleinformatyczne podtrzymują funkcjonowanie tego systemu, zapewniając szybką komunikację i efektywną wymianę informacji. Sprzyjają tym samym rozwojowi rynku książki, podobnie jak wspomniane wcześniej działania różnych podmiotów uczestniczących w procesach produkcji, dystrybucji i użytkowania dzieł piśmienniczych. Stały napływ nowych tytułów czy zwiększający się zbiór wiadomości o nich nie musi jednak mieć bezpośredniego przełożenia na łatwość, z jaką czytelnicy będą w stanie pozyskać te książki, których poszukują. Ann Steiner (2018) scharakteryzowała pozornie dobroczynny wpływ nowych mediów na funkcjonowanie przemysłu wydawniczego w następujący sposób: „Chociaż technologia sprawiła, że publikowanie stało się łatwiejsze i tańsze, trudniej jest przyciągnąć uwagę i zapewnić sprzedaż" (tłumaczenie własne - M.G.). Kluczową kwestią dla sprawnego funkcjonowania rynku książki stały się zatem wszelkie działania mające na celu łączenie klientów z tytułami mieszczącymi się w sferze ich zainteresowań czytelniczych, za które są skłonni zapłacić.

Bogactwo informacji występujących w środowisku sieciowym decyduje o tym, że książki konkurują nie tylko między sobą o uwagę potencjalnych nabywców i/lub czytelników, ale także z innymi produktami, które podlegają sprzedaży. W obliczu wszystkich dostępnych w internecie źródeł wiedzy o książkach możliwości wyboru związane z określonymi decyzjami zakupowymi czy lekturowymi są więc ogromne. Niezwykle istotna i cenna staje się zatem znajomość zachowań użytkowników w sieci, szczególnie w kontekście ich zwyczajów konsumenckich. Ważniejsze jest jednak zapewnienie odpowiednich warunków, dzięki którym klienci łatwo natrafią na poszukiwane tytuły podczas wędrówek po stronach internetowych. Kontaktowi z książką ogólnie sprzyja jej widoczność (ang. visibility), dzięki czemu pewne pozycje mają szansę wyróżnić się z masy bieżącej produkcji wydawniczej i przeniknąć do powszechnej świadomości. Zapewnienie książce widoczności wiąże się w pewnym stopniu z wykorzystaniem tradycyjnych narzędzi marketingowych (na przykład związanych z przyznanymi autorowi nagrodami), za sprawą których dana publikacja staje się przedmiotem powszechnego dyskursu, a niekiedy wręcz wydarzeniem medialnym. Określone tytuły można również wyróżnić poprzez odpowiednią ich ekspozycję w księgarniach lub na witrynach internetowych czy też za pomocą billboardów ulicznych (Steiner, 2018). Osiągnięcie przez wydawcę wysokiej widoczności książek często wiąże się z koniecznością zastosowania przez niego odpowiednich strategii reklamowych, które obejmują jednak tylko wybrany fragment oferty wydawniczej. W szerszym zakresie wydawnictwo może wzbudzić zainteresowanie swoimi produktami za sprawą wy- 
krywalności (ang. discoverability), która łączy się z wykorzystaniem metadanych, wyszukiwarek internetowych oraz innych narzędzi organizacji informacji w środowisku cyfrowym. Wykrywalność obiektów lub treści w sieci oznacza zapewnienie możliwości ich łatwego wyszukania oraz stworzenie odpowiednich warunków do ich wyeksponowania w danym zbiorze. Stopień wykrywalności danego tytułu w zasobach internetowych wskazuje na to, z jaką łatwością można go odnaleźć, a także jak bardzo dany tytuł wyróżnia się na tle konkurencji (pozostałych książek lub innych produktów). Wysoką wykrywalność publikacji książkowych w sieci zapewnia przede wszystkim odpowiednio dobrany zestaw metadanych, które umożliwiają sprawną i rozległą dystrybucję informacji o nich i mają zasadniczy wpływ na ich indeksowanie przez wyszukiwarki (zarówno globalne - na przykład Google — jak i lokalne — instalowane bezpośrednio w witrynie) ${ }^{1}$.

Oprócz metadanych w zakresie wykrywalności obiektów w sieci ważne są również wszelkie działania, które wykorzystują profesjonalne narzędzia informatyczne do organizowania i udostępniania zbiorów informacji cyfrowych na zasadach zgodnych $\mathrm{z}$ regułami architektury informacji oraz pozycjonowania stron internetowych. Działania te mogą się różnić w zależności od środowiska, w którym książki mają być prezentowane i wyszukiwane, ponieważ inne czynniki będą decydowały o wykrywalności obiektów cyfrowych w serwisie, a inne ogólnie w internecie (Sim, 2017). W księgarni internetowej klienci poszukują tytułów znajdujących się w otoczeniu innych książek, stąd istotną rolę odgrywa trafny dobór słów kluczowych oraz właściwa klasyfikacja asortymentu w ramach kategorii widniejących na witrynie. Zbyt ogólne sformułowanie kategorii (literatura, poradniki, biografie itp.) katalogów tematycznych w księgarniach online udostępniających bogatą ofertę tytułową może skutkować koniecznością obejrzenia przez klientów ogromnej liczby pozycji. W procesie przeglądania zawartości witryny księgarni czy wydawnictwa w celach zakupowych istotne znaczenie ma również sposób prezentacji oferty tytułowej, obejmujący układ strony, typografię, kolorystykę, linkowanie, dostępne funkcje (na przykład w zakresie możliwości składania zamówień produktów) itp. Większą rangę przypisuje się jednak wykrywalności książek realizowanej z wykorzystaniem wyszukiwarek internetowych. W tym przypadku konkuruje ona nie tylko z innymi tytułami, ale także produktami czy treściami dostępnymi w sieci. W kontekście jej sprzedaży najważniejsze jest zatem jak najwyższe miejsce określonego tytułu w wynikach wyszukiwania. Działania na rzecz uzyskania takiego efektu mają charakter złożony, najczęściej łączą się jednak z dodawaniem odpowiednich znaczników metadanych i sporządzaniem

1 Jednym z najpopularniejszych światowych standardów w zakresie metadanych wykorzystywanych w dystrybucji i sprzedaży książek jest ONIX (ONline Information eXchange), który pozwala na ,automatyczne przetwarzanie informacji o produkcie i wykorzystanie jej w katalogach, księgarniach internetowych i w materiałach promocyjnych” (Jaskowska, 2020, s. 30). 
oryginalnych komunikatów analizowanych przez mechanizmy indeksujące, co zbiorczo określa się jako optymalizację pod kątem wyszukiwarek (ang. search engine optimization).

Elementem wykrywalności jest łatwość, z jaką użytkownik odnajduje produkty i usługi w sieci, co może być utożsamiane z wyszukiwalnością (ang. findability). W kontekście marketingu i zarządzania wiedzą wykrywalność i wyszukiwalność oznaczają jednak dwie różne koncepcje kojarzenia uży tkownika z informacją sieciową. Wyszukiwalność łączy się z odnajdowaniem treści, o których użytkownik wie, że istnieją, podczas gdy wykrywalność pozwala mu trafić na informacje, których wcześniej nie znał. Jeśli zatem internauta zna autora i tytuł poszukiwanej przez siebie książki, wysoka wyszukiwalność pozwoli mu za pomocą wyszukiwarki i niewielkiej liczby kliknięć szybko dotrzeć do witryny (na przykład księgarni internetowej, portalu literackiego czy serwisu dla czytelników), na której znajdzie wszelkie związane z tą publikacją informacje. Wykrywalność natomiast wiąże się również z mniej oczywistymi działaniami użytkowników w zakresie odnajdowania treści cyfrowych. Chodzi bowiem o łatwość dotarcia do informacji, których poszukiwanie nie jest przez użytkowników skonkretyzowane, a także proponowanie im informacji, które byłyby dla nich przydatne i odpowiadałyby na ich potrzeby. W przypadku książki, oprócz wspomnianych wcześniej metod i narzędzi, wysoką wykrywalność są w stanie zapewnić również systemy czy też silniki rekomendacji.

\section{AUTOMATYCZNE REKOMENDACJE KSIAZŻEK}

W Stowniku języka polskiego pod redakcją Witolda Doroszewskiego (https:// sjp.pwn.pl/doroszewski/lista) definicja słowa „rekomendacja” jednoznacznie łączy je z pochlebną opinią wydaną o kimś pisemnie lub ustnie bądź z poleceniem kogoś. Językoznawcy podkreślają dotychczasowy pozytywny wydźwięk tego wyrazu, jednak dopuszczalne są również inne konteksty, w których on występuje. Stąd w Słowniku języka polskiego PWN (https://sjp.pwn.pl) oznacza on zarówno pozytywną opinię na temat danej osoby, jak i pozytywną lub negatywną ocenę wartości spółki i jej akcji przygotowaną przez doradcę giełdowego.

W obszarze nauk o zarządzaniu funkcjonuje pojęcie marketingu rekomendacji, stanowiącego jedną z nazw marketingu szeptanego (ang. word-of-mouth), który łączy się z wyrażaniem osobistych opinii o firmach, produktach i usługach oraz rozpowszechnianiem ich za pomocą odpowiednich narzędzi, wśród których szczególne miejsce zajmują technologie teleinformatyczne. Rekomendacje stały się charakterystycznym elementem współczesnych praktyk biznesowych realizowanych w środowisku sieciowym. Systemy rekomendacji (ang. recommendation 
systems) produktów, zwane również silnikami rekomendacji (ang. recommendation engines), są wykorzystywane na platformach e-commerce do sugerowania klientom treści, które mogą ich zainteresować. W odniesieniu do dużej liczby obiektów występujących w zbiorze działają na zasadzie filtrów ograniczających ich wybór do wyselekcjonowanych na podstawie różnych kryteriów pozycji. Stanowią one obecnie ważny element strategii sprzedażowej online ze względu na spersonalizowany charakter wyborów dokonywanych przez klientów, który nawiązuje do sytuacji towarzyszącej robieniu zakupów w sklepie stacjonarnym.

Systemy rekomendacji działają na podstawie analizy różnych danych (obejmujących zachowania użytkowników na danej witrynie i informacje o występujących tam obiektach). Bazują one na obliczeniach dokonywanych w trybie offline i wymagają przygotowania modelu danych, który następnie jest przetwarzany w czasie rzeczywistym (Flis, 2015, s. 95). Wśród różnych technik informatycznych umożliwiających generowanie polecanych treści najczęściej stosowane są rekomendacje wytypowane i zaproponowane użytkownikowi na podstawie podobieństw w zakresie jego preferencji z wyborami innych użytkowników (ang. collaborative filtering recommendation) oraz wynikające $\mathrm{z}$ analogii w zakresie elementów opisu, cech czy zawartości treściowej danego obiektu (ang. content-based recommendation). W pierwszym przypadku analizowane są działania użytkowników (związane z wyszukiwaniem informacji, dokonywaniem zakupów itp.), a nie właściwości obiektów, których one dotyczą. W drugim natomiast algorytm wyszukuje podobieństwa pomiędzy elementami charakteryzującymi różne obiekty i podpowiada internaucie, na które $\mathrm{z}$ nich warto zwrócić uwagę. W wielu przypadkach oba podejścia łączone są $\mathrm{w}$ jeden mechanizm filtrujący (ang. hybrid recommender system), który uwzględnia zarówno preferencje użytkowników, jak i cechy obiektów występujących w danym zbiorze.

Szczególną rolę w filtrowaniu informacji sieciowych odgrywają systemy rekomendacji książek (ang. book recommendation systems) i innych dokumentów piśmienniczych (na przykład artykułów). Upraszczają złożony proces podejmowania decyzji dotyczących wyboru dokumentu poprzez zaproponowanie użytkownikowi pozycji wyselekcjonowanych z przeszukiwanego przez niego zbioru. Obok wyszukiwarek, katalogów tematycznych, zestawów kategorii stanowią one kolejne narzędzie informatyczne pozwalające internaucie na dotarcie do interesujących go publikacji. Od innych mechanizmów wyszukiwawczych różni je sposób działania, który oparty jest na preferencjach lekturowych czytelników oraz ich aktywności w sieci. Systemy rekomendacji wykorzystywane są w dystrybucji informacji naukowej — na przykład do wyszukanych artykułów w bazie ScienceDirect wydawnictwa Elsevier dołączany jest zestaw polecanych tekstów wygenerowany na podstawie algorytmu porównującego publikacje $\mathrm{z}$ historii wyszukiwań użytkowników z danymi cytowań w bazie Scopus. Największe znaczenie mają 
one jednak w kontekście optymalizacji sieciowej sprzedaży książek. Charakterystycznym silnikiem rekomendacji dla księgarń internetowych jest mechanizm bazujący na filtrowaniu grupowym typu item-to-item, do którego popularyzacji przyczyniła się firma Amazon. Dla każdej zakupionej książki algorytm znajduje podobne tytuły, a następnie tworzy na tej podstawie listę rekomendacji. W celu określenia najbardziej trafnego dopasowania produktów system buduje ich zestawienie poprzez odnajdowanie tytułów, które klienci zwykle kupują razem (Linden, Smith, York, 2003).

Silniki rekomendacji książek w księgarniach internetowych nastawione są na automatyczne gromadzenie informacji o działaniach podejmowanych przez klientów. Każde wyświetlenie informacji o konkretnej publikacji jest analizowane przez algorytm i skutkuje przedstawieniem kolejnych propozycji tytułowych. Efektem tych działań ma być zwiększona sprzedaż książek, również tych, które nie pojawiły się bezpośrednio w zapytaniu klienta. Zakupy książkowe nie zawsze jednak są połączone z zainteresowaniami i preferencjami czytelników, ponieważ ich cele mogą mieć wspomniany już charakter pozalekturowy. Inne zadania realizują silniki rekomendacji instalowane w ramach witryn przeznaczonych dla miłośników literatury. Serwisy społecznościowe dla czytelników oferują szeroki zakres aktywności odwołujących się do tradycyjnych zachowań czytelniczych (tworzenie spisów książek, wymiana informacji o przeczytanych tytułach, ich opiniowanie, recenzowanie, a także kontakty z innymi czytelnikami), ale przede wszystkim zawierają bogate i obszerne bazy danych, których przetwarzanie może być podstawą do projektowania kolejnych usług. Najbardziej charakterystycznym przykładem wykorzystania zasobu serwisu społecznościowego czytelników do stworzenia systemu rekomendacji jest Goodreads. Jego silnik rekomendacji analizuje powiązania między tytułami, sprawdzając, jak często pojawiają się one na tych samych półkach z książkami różnych użytkowników i czy zostały przez nich podobnie ocenione (Chung, 2011). Dzięki stałemu powiększaniu się kolekcji publikacji oraz ich opiniowaniu przez czytelników silnik rekomendacji uczy się coraz więcej o podobieństwach i różnicach gustów czytelniczych użytkowników tego serwisu.

System rekomendacji książek Goodreads stanowi jedną z wielu usług oferowanych w ramach tej witryny. W sieci dostępne są jednak serwisy społecznościowe, których główną funkcją jest oferowanie czytelnikom kolejnych propozycji lekturowych dostosowanych do ich upodobań. Witryny tego typu oparte są na różnych systemach rekomendacji książek, a wykorzystywane w nich silniki analizują analogie w zestawach ulubionych lektur lub podobieństwa w preferowanych przez czytelników treściach.

Usługa serwisów rekomendujących książki opartych na podobieństwie preferencji lekturowych polega na tym, że użytkownik otrzymuje listę proponowanych 
tytułów, które są skojarzone ze wskazaną przez niego wcześniej publikacją. Wykaz książek jest generowany na podstawie zestawień innych czytelników (zakłada się, że jeśli ktoś lubi dwóch autorów, to następna osoba lubiąca jednego z nich polubi również drugiego). W tego typu systemach najczęściej wykorzystywana jest technologia collaborative filtering.

Jednym z najstarszych tego typu projektów jest Gnod Literature Marka Gibneya. Serwis ten działa w internecie od 2002 roku i bazuje na gromadzeniu danych o preferencjach lekturowych użytkowników. W odniesieniu do książek dostępne są dwie możliwości generowania rekomendacji. Pierwsza część projektu to Gnooks (https://www.gnooks.com), gdzie czytelnik wskazuje trzy nazwiska ulubionych autorów, a następnie system proponuje mu kolejnych dziesięciu pisarzy. Dzięki oznaczeniu przez użytkownika każdej z tych pozycji w odpowiedni sposób („lubię”, „nie lubię”, „nie znam”) system gromadzi wiedzę o połączeniach pomiędzy twórcami. Drugą częścią projektu jest Literature-Map (https://www. literature-map.com), gdzie wizualizowane są powiązania pomiędzy autorami, wygenerowane na podstawie preferencji czytelników. Wpisanie dowolnego pisarza powoduje wyświetlenie chmury nazwisk, w środku której znajduje się wskazana osoba. Nazwiska w pobliżu centrum oznaczają bliskie powiązania, a co za tym idzie, najwyższe prawdopodobieństwo polubienia również tych autorów. Następnym serwisem polecającym książki z tej kategorii jest What Should I Read Next? (https://www.whatshouldireadnext.com), udostępniany w internecie od 2005 roku. Generowanie rekomendacji odbywa się po wpisaniu nazwiska autora lub tytułu. Uzyskany wykaz proponowanych publikacji stanowi efekt działania algorytmu, którego podstawą jest kojarzenie $\mathrm{z}$ sobą pozycji pojawiających się na różnych listach czytelników tworzących społeczność portalu. Im częściej poszczególne tytuły trafiają na różne listy, tym silniejsze zachodzą między nimi związki. Z kolei Readgeek (https://www.readgeek.com) to nazwa internetowego silnika rekomendacji, ale także istniejący od 2010 roku serwis społecznościowy dla czytelników. Uzyskanie wykazu rekomendowanych książek wymaga od użytkownika dokonania oceny przynajmniej kilkunastu tytułów w skali od zera do dziesięciu. Następnie system porównuje te dane z preferencjami innych czytelników i po odnalezieniu podobnych wskazań generuje listę propozycji książkowych. Przykładem witryny pełniącej funkcje systemu rekomendacji książek i serwisu społecznościowego jest również Bookfinity (https://bookfinity.com), dostępny w internecie od 2020 roku i opracowany przez firmę Ingram, specjalizującą się w usługach dla klientów z branży wydawniczej. Wykorzystany w nim system rekomendacji oparty jest na grupowaniu czytelników na podstawie nie tylko ich preferencji lekturowych, lecz także szeregu innych informacji. Każdy zainteresowany rekomendacjami użytkownik wypełnia quiz, w którym określa ulubione tytuły czy gatunki książek (ale także filmów) i charakteryzuje swoje zachowania lekturowe. Wskazuje również projekty okładek, które mu się podobają i odpowiada na pyta- 
nia odnoszące się ogólnie do jego zainteresowań (na przykład hobby) oraz stylu życia. W efekcie analizy tych danych internauta zostaje przypisany do jednego z 18 profili czytelniczych i otrzymuje spersonalizowany zestaw kilkunastu tytułów. Preferencje czytelnika są na bieżąco weryfikowane, ponieważ każdą pozycję z listy można ocenić jako właściwą lub nietrafioną, co skutkuje wprowadzeniem do niej odpowiednich modyfikacji.

Skuteczność systemów rekomendacji tytułów opartych na kojarzeniu publikacji pojawiających się na listach różnych czytelników zależy od wielkości bazy książek, a także od ich popularności, ponieważ im większa liczba wskazań ulubionych pozycji, tym sprawniej można generować połączenia między nimi. W serwisach, w których użytkownicy sami wpisują ulubione lektury, mogą jednak zdarzać się problemy związane z błędnie zapisanymi tytułami lub nazwiskami autorów, powtarzaniem się tytułów odnoszących się do różnych wydań tej samej książki, a także występowaniem publikacji lub autorów, którzy nie będą skojarzeni z żadnymi obiektami w bazie ze względu na zbyt małą liczbę ich wystąpień na listach. Z kolei w systemach, w których listy książek opracowują twórcy witryny, problemem są braki w tytułach - nie wszystkie publikacje danego autora są uwzględniane w bazie, ponieważ zakłada się, że jeśli czytelnik polubi jedną jego książkę, będzie chciał przeczytać również inne. Wykorzystanie tego typu systemów w serwisach o charakterze społecznościowym pozwala jednak na stałą aktualizację danych i rekomendacji nie tylko przez autorów projektu, lecz także jego użytkowników.

Kolejną grupę witryn dla czytelników stanowią serwisy rekomendujące książki oparte na kategoryzacji treści. Systemy typu content-based recommendation analizują podobieństwa w zakresie zawartości książek i obejmują na przykład ogólną wymowę utworu, panujący w nim nastrój czy konkretne elementy fabuły (bohaterowie, miejsce akcji itp.). W odróżnieniu od wcześniej wymienionych systemów ich algorytmy uwzględniają bliskość kategorii przypisanych poszczególnym tytułom, a nie ich obecność na listach ulubionych lektur czytelników.

Przykładem zastosowania tego typu rozwiązania jest projekt WhichBook (https://www.whichbook.net), funkcjonujący w internecie od 2002 roku i realizowany przez Opening the Book - firmę zajmującą się szkoleniami dla bibliotekarzy oraz wyposażaniem bibliotek. Czytelnik, korzystając z tego serwisu, otrzymuje wykaz tytułów, które są dopasowane do wskazanych przez niego preferencji. Silnik rekomendacji wykorzystywany w ramach tego projektu oparty jest na kategoryzacji treści książek, a poszczególne utwory zostały skojarzone ze względu na ich nastrój i emocje towarzyszące lekturze. Czytelnik może zatem uzyskać interesujący go zestaw książek, wybierając odpowiedni współczynnik mieszczący się w przedziale pomiędzy lekturą łatwą, przyjemną, rozweselającą, przewidywalną i relaksacyjną, a lekturą poważną, wymagającą, posępną, niepokojącą lub wręcz wywołującą obrzydzenie. Inne kryteria doboru publikacji obejmują miejsce akcji, cechy charakteryzujące głównego bohatera oraz elemen- 
ty odnoszące się do szczegółów fabuły. Proponowane tytuły najczęściej dobierane są niezależnie od wskazań gatunkowych, co może być traktowane przez czytelników jako zaleta lub wada. Na przykład książki zawierające sporą dawkę przemocy są zaliczane zarówno do kryminałów, jak i literatury faktu, czego nie muszą akceptować wielbiciele fikcyjnych opowieści, ale inni użytkownicy serwisu mogą być usatysfakcjonowani proponowaną różnorodnością gatunkową. Podobny mechanizm rekomendacji został wykorzystany również w polskim serwisie CoDoCzytania (https://codoczytania.pl), który powstał na bazie realizowanego od 2018 roku przez spółkę Literacka projektu. Jego główną ideą było wykorzystanie komputerowych technik przetwarzania języka naturalnego i uczenia maszynowego do stworzenia inteligentnego systemu rekomendacji książek, ułatwiającego czytelnikom dokonywanie wyborów lekturowych (Literacka, 2018). Podobnie jak w przypadku WhichBook, tytuły kojarzone są z sobą ze względu na podobieństwa określonych parametrów fabuły. Czytelnik otrzymuje zestaw rekomendowanych książek po wskazaniu własnych preferencji w zakresie miejsca akcji, scen zawierających przemoc, realizmu i jego braku, występowania erotyki, wymowy optymistycznej lub pesymistycznej, obecności humoru, wątków romansowych czy intensywności doznań lekturowych. W tym serwisie czytelnik może ponadto wskazać konkretny interesujący go gatunek literacki.

Systemy rekomendacji książek oparte na analizie treści wymagają od czytelnika głębszej autorefleksji na temat własnego gustu czy preferencji lekturowych, która wykracza poza wskazanie ulubionych autorów, tytułów i gatunków. Użytkownik korzystający z takiego rozwiązania jest zobligowany do zastanowienia się nad tym, w jaki sposób odbiera treści książek w powiązaniu z różnymi sytuacjami i kontekstami towarzyszącymi lekturze oraz swoimi preferencjami w tym zakresie. Skuteczność tego typu systemów zależy od trafności i szczegółowości kryteriów, na których podstawie dopasowywane są poszczególne tytuły. Zestaw wskaźników decydujących o tym, że pewne książki mogą się podobać czytelnikom, a inne nie, jest definiowany przez twórców projektu, którzy mogą jednak korzystać ze wsparcia ochotników, zajmujących się weryfikacją trafności rekomendacji.

\section{PODSUMOWANIE}

Systemy rekomendacji książek stanowią atrakcyjne narzędzie zapewniania użytkownikom dostępu do poszukiwanych przez nich informacji o piśmiennictwie. W obliczu stale rosnących zasobów sieci mogą przyczynić się do szybszego 
wyszukiwania publikacji, ale także do pozyskiwania informacji, które nie zostałyby odnalezione innymi metodami. Właściwością odróżniającą tego typu narzędzia od innych mechanizmów wyszukiwawczych jest ich spersonalizowany charakter, wynikający z analizy konkretnych preferencji lekturowych. Systemy rekomendacji książek wspomagające wybory dokonywane przez czytelników cechuje różny stopień szczegółowości: niekiedy wystarczy wpisać nazwisko autora lub tytuł ulubionej pozycji, w innych przypadkach ważne jest precyzyjne wskazanie własnych inklinacji czytelniczych, a także ujawnienie innych osobistych informacji. Sprawność ich działania uzależniona jest przede wszystkim od wielkości zbioru ty tułów i odpowiedniej liczby czytelników, co wiąże się z możliwością generowania połączeń pomiędzy publikacjami. Rozwój systemów tego typu wspomagany jest również przez algory tmy uczenia maszynowego (ang. machine learning), które analizują każde kolejne działania podejmowane przez użytkowników (na przykład ocenianie trafności rekomendacji). Silniki rekomendacji znajdują obecnie zastosowanie przede wszystkim na stronach księgarni internetowych, ale coraz częściej pojawiają się również w serwisach przeznaczonych do rozwijania pasji czytelniczych, przede wszystkim w ramach wirtualnych społeczności.

Korzyści wynikające ze stosowania systemów rekomendacji książek nie powinny jednak przesłaniać problemów, które wiążą się z ich upowszechnieniem. Ponieważ podstawą ich działania są filtrowanie i selekcjonowanie informacji, istnieje niebezpieczeństwo, że generowane przez nie rekomendacje będą pomijać istotną część produkcji wydawniczej, a na kolejnych listach może się pojawiać ten sam zestaw najpopularniejszych tytułów. Wygenerowane automatycznie rekomendacje dostarczają użytkownikowi lektur, które w mniejszym lub większym stopniu są zgodne z jego preferencjami, co może jednak przyczyniać się do tego, że czytelnik pozostanie w obrębie zamkniętego kręgu lekturowego, niekoniecznie sprzyjającego poszerzaniu jego horyzontów literackich. Silniki rekomendacji mogą również powodować zmiany w sposobach pozyskiwania wiedzy. Użytkownicy zamiast własnych poszukiwań lekturowych (które mogą być pracochłonne, ale same w sobie pozwalają nabyć wiedzę i pozyskać niespodziewane informacje) będą na przykład polegać wyłącznie na tytułach proponowanych przez algorytmy komputerowe. $Z$ kolei ich twórcy podczas projektowania całego mechanizmu doradzającego lektury mogą się kierować własnymi interesami (biznesowymi, światopoglądowymi, politycznymi itp.). Niezbędne są zatem bardziej szczegółowe badania jakości systemów rekomendacji książek, również w zakresie podmiotów (wydawców, księgarni), autorów, gatunków, które dominują w systemach rekomendacji, a także ich wpływu na współczesną kulturę książki. 


\section{BIBLIOGRAFIA}

Andrzejewska, J. (1989). Kultura czytelnicza jednostki jako program edukacji czytelniczej i przedmiot badań. Studia o Ksiażce, 18, 34-63.

Baverstock, A. (2019). Marketing for Publishing. In: A. Phillips, M. Bhaskar (Ed.), The Oxford Handbook of Publishing. Oxford: Oxford University Press. http://doi.org/10.1093/oxford$\mathrm{hb} / 9780198794202.013 .15$.

Bunyard, D. (2020). Why we buy books. Logos. Journal of the World Publishing Community, 31(2), $28-51$.

Chung, K. (2011, 15 września). Announcing Goodreads Personalized Recommendations, Goodreads. https://www.goodreads.com/blog/show/303-announcing-goodreads-personalized-recommendations.

Chymkowski, R., Zasacka, Z. (2021). Stan czytelnictwa w Polsce w 2020 roku. Warszawa: Biblioteka Narodowa. https://www.bn.org.pl/download/document/1621420376.pdf.

Flis, K. (2015). Personalizacja, rekomendacja, prosumpcja - trzy wymiary dialogu organizacji i konsumenta. Handel Wewnętrzny, 1(354), 92-100.

Jaskowska, M. (2020). Publiczne systemy informacyjne i źródła danych. Przewodnik. Kraków: Uniwersytet Jagielloński — Biblioteka Jagiellońska. https://ruj.uj.edu.pl/xmlui/handle/ item/152126.

Koryś, I., Chymkowski, R. (2019). Stan czytelnictwa w Polsce w 2018 roku. Wstępne wyniki. Warszawa: Biblioteka Narodowa. https://www.bn.org.pl/download/document/1587250668.pdf.

Linden, G., Smith, B., York, J. (2003). Amazon.com recommendations. Item-to-item collaborative filtering. IEEE Internet Computing, 7(1), 76-80. http://doi.org/10.1109/MIC.2003.1167344.

Literacka Sp. z o.o. (2018, 29 października). O projekcie: Automatyczny Recenzent - inteligentny system rekomendacji książek. https://literacka.com.pl/2018/10/29/systemrekomendacyjny/.

Mikkonen, A., Vakkari, P. (2016). Readers' interest criteria in fiction book search in library catalogs. Journal of Documentation, 72(4), 696-715.

Sim, C. (2017). SEO Beyond Google. Publishers Weekly, 264(28), 92.

Sobczyk, G. (2018). Zachowania konsumentów wobec nowych trendów konsumpcji — wyniki badań. Annales Universitatis Mariae Curie-Skłodowska. Sectio H. Oeconomia, 52(1), 171-180.

Steiner, A. (2018). The Global Book: Micropublishing, Conglomerate Production, and Digital Market Structures. Publishing Research Quarterly, 34, 118-132.

Wojciechowski, J. (1999). Czytelnictwo. Kraków: Wydawnictwo Uniwersytetu Jagiellońskiego.

Woźniak-Kasperek, J., Kotuła, S. (2014). Komunikacja bibliologiczna i książka w przestrzeni sieci — pytania o tożsamość poznawczą i terminologiczną. W: A. Cisło, A. Łuszpak (Red.), Kulturowa tożsamość książki (ss. 9-25). Wrocław: Wydawnictwo Uniwersytetu Wrocławskiego.

Zasacka, Z. (2009). Dlaczego czytamy powieści - kilka implikacji dla badaczy czytania dla przyjemności. Przegląd Humanistyczny, 3(414), 81-93.

Zawisza, J.W. (1980). Propozycja schematu komunikacji bibliologicznej. Studia o Książce, 10, 39-58. 


\section{THE JOY OF READING AND THE AGONY OF CHOICE. A SELECTION OF TECHNOLOGIES FOR DETECTING AND RECOMMENDING BOOKS ON THE INTERNET}

\section{Summary}

Throughout the period of political transition (from communism), the Polish book market has seen a consistent growth in the number of titles on offer. In 2019, the National Library received samples of over 36 thousand published book titles, which included almost 10 thousand literary texts. If we take into account publications that were not transferred to the NL, copies from past years, or titles remaining in bookshops, antique shops, public libraries and private collections; we end up with a vast amount of literary content, which should allow for the needs of any and all readers to be met. In the face of this plentiful and varied selection, finding titles which will fulfil specific intellectual, emotional or aesthetic needs is thus becoming a considerable challenge for readers. The specifics of the modern publishing market also results in the companies who publish and distribute books have begun to look for increasingly algorithm-driven methods for delivering an assortment to their clients which matches their individual reading preferences. The goal of this paper is to discuss specific methods for the effective display of books online, and for delivering a personalized title offering to readers. The subject of the paper are so called ,book recommendation systems". The research methods used are analysis and critique of existing literature and analysis of online content (web pages). The end result of the research is to distinguish specific types of book recommendation systems.

KEY WORDS: Reading, publishing market, online visiblity of books, positioning of books (in search engine results), book recommendation systems 